\begin{tabular}{|c|c|}
\hline \multirow{3}{*}{ 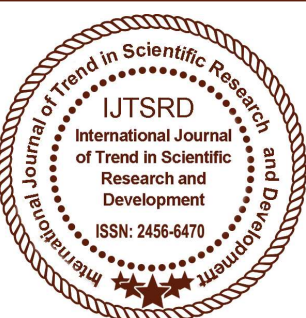 } & $\begin{array}{l}\text { International Journal of Trend in Scientific } \\
\text { Research and Development (IJTSRD) }\end{array}$ \\
\hline & International Open Access Journal \\
\hline & ISSN No: 2456 - 6470 | www.ijtsrd.com | Volume - 2 | Issue -3 \\
\hline
\end{tabular}

\title{
A Study on Students Attitude Towards Entrepreneurship in Selective College From Coimbatore City
}

\author{
Mary Diana A \\ Assistant Professor, Department of Commerce \\ Rathinam College of Arts and Science, Eachanari, India
}

\begin{abstract}
The present article is an attempt that has been made to study the students 'attitude towards Entrepreneurship at Coimbatore City. Entrepreneurship is an area importance has raised multi fold over the last few decades around the world and in the last couple of decades in India. Entrepreneurship has become an everyday buzzword. Policymakers, economists, academics and even university students are talking about it. Seminars, Conferences and workshops are being organized every year across the world which emphasized on the importance of entrepreneurship to country, society as well as for the individual development. Today, there is big question raised in the minds of management students i.e., "Which way to go" either to go organizational development or to opt. Entrepreneurship as a career. It has been well recognized that the career choice is a very complicated and multifaceted process and will play a very important role in the life and development of students. To give a deep insight to answers those questions the current study is also discusses about the student's attitude towards Entrepreneur. What type of barriers they are facing while selecting entrepreneur as a career.
\end{abstract}

\section{INTRODUCTION:}

Entrepreneurship is the development of a business from the ground upcoming up with an idea and turning it into a profitable business. But while the definition of entrepreneurship may be simple, its execution is much more difficult. "Entrepreneurship is the journey of opportunity exploration and risk management to create value for profit and or social good. Gottlieb said that an entrepreneur is someone

who can take any idea, whether it be a product and/or service, and have the skill set, will and courage to take extreme risk to do whatever it takes to turn that concept into reality and not only bring it to market, but make it a viable product and/or service that people want or need.

An entrepreneur but there is certain characteristics that most successful entrepreneurs possess, Ability to plan

- Communication Skills

- Marketing skills

- Basic Management Skills

- Interpersonal Skills

- Leadership Skills

They are the risk taker and it is the prime motive that should be developed in the students. Students are the forth comer who can become an entrepreneur Entrepreneurship plays an important role in the rise and prosperity of a nation by cultivating the students and young entrepreneurs with innovation and entrepreneurial capacity, which enhances their competitiveness of employment and development under the circumstance of finance crisis. Successful entrepreneurs are those which always learn from their failures; which always tried to solve problems; tried to strength their weakness and make sure that this is what we actually want.

\section{REVIEW OF LITERATURE:}

Many studies have revealed that entrepreneurs are not naturally conceived but made through their environment and experiences as they develop and 
learn being impacted by guardian, mentors, tutors, instructors role model during their development process.

Many studies have revealed that entrepreneurs are not naturally conceived but made through their environment and experiences as they develop and learn, being impacted by guardian, mentors, tutors, instructors role model during their development process (Teixeira and Davey, 2008)[12].The perspectives and believes of students toward entrepreneurship are the results of their immediate social and cultural environment. Consequently, the orientation and conducts of youth and young graduates are affected by various individual and ecological variables, which imply that the decision and desirability of becoming an entrepreneur or employee is a reflection of environmental and economic forces (Alain, Benoit and Clerc Narcissi 2006)[13]. Education about entrepreneurship and for entrepreneurship has the capacity of increasing students" interest in becoming entrepreneurs at some stage after completing their university degrees (Friendrich and Visser, 2005)[14]. Perceptions and attitudes of the youth towards entrepreneurship do vary among countries (Green \& Pryde, 1990)[15]. In Canada, almost all the youth would like to start their own business some day but only half think they will, and the biggest barriers being fear of financial failures, lack of strong identity with the entrepreneurial role and lack of knowledge about the first step to take (Green and Pryde, 1990)[15].

\section{RESEARCH METHODOLOGY}

Present study is exploratory cum descriptive in nature. The sample size is 500 respondents. Data were collected from the selective colleges (BBA and MBA students) from Coimbatore city. Respondents participation was voluntarily \& completely anonymous. Only those MBA \& BBA students are consulted who are pursuing their course \& doesn't include those students who have passed out.

\section{OBJECTIVES OF THE STUDY:}

To analyze the factors influencing the students attitude towards entrepreneurship.

To evaluate the perception level about the factors that led to the emergence of entrepreneurs in future period

\section{LIMITATIONS OF THE STUDY:}

The study is micro level and limited to only one department of Bharathiyar University, Coimbatore. This study is conducted bearing in mind the sample size of five hundred students. The management degree pursuing students of Bharathiyar University are the respondents which may not rationalize the survey as the view of students of other educational institute may differ. Because of bias and opinions of respondents, some responses of the questionnaire may differ from the reality.

\section{ANALYSIS AND INTERPRETATION}

\section{Gender of The Respondents}

From the above table $63 \%$ of the respondents were male and remaining $37 \%$ of them were female. Majority $63 \%$ of the respondents were male.

\section{Age Group Of The Respondents}

\begin{tabular}{|l|l|l|l|}
\hline S.No & Age & Frequency & Percentage \\
\hline 1 Jour & Below 18 & 151 & 30.02 \\
\hline 2 cien & $18-25$ & 300 & 60.00 \\
\hline 3 and & $25-40$ & 49 & 9.08 \\
\hline ment & Total & 500 & 100.00 \\
\hline
\end{tabular}

From the above table $60 \%$ of the respondents were $18-25$ years, below 18 years or $30.2 \%$ and remaining $9.8 \%$ of them were $25-40$. Majority $60 \%$ of the respondents belong to the age group of 18-25 years.

\section{Educational Qualification Of The Respondents}

\begin{tabular}{|l|l|l|l|}
\hline S.No & $\begin{array}{c}\text { Educational } \\
\text { Qualification }\end{array}$ & Frequency & Percentage \\
\hline 1 & Graduation & 236 & 47.02 \\
\hline 2 & $\begin{array}{l}\text { Post } \\
\text { graduation }\end{array}$ & 109 & 28.08 \\
\hline 3 & Diploma & 151 & 30.02 \\
\hline 4 & Others & 4 & 8 \\
\hline & Total & 500 & 100.00 \\
\hline
\end{tabular}

From the above table $47.2 \%$ of the respondents have 
completed school education, $30.2 \%$ of them have completed diploma, $28.8 \%$ of them have completed post graduate, and $8.8 \%$ of them completed others. Most $47.2 \%$ of the respondents have completed school education.

\section{Course of The Respondents}

\begin{tabular}{|l|l|l|l|}
\hline S.No & \multicolumn{1}{|c|}{ Course } & Frequency & Percentage \\
\hline 1 & Commerce & 264 & 52.08 \\
\hline 2 & $\begin{array}{l}\text { Computer } \\
\text { science }\end{array}$ & 32 & 6.04 \\
\hline 3 & $\begin{array}{l}\text { Management } \\
\text { stream }\end{array}$ & 27 & 5.04 \\
\hline 4 & Others & 177 & 35.04 \\
\hline & Total & 500 & 100.00 \\
\hline
\end{tabular}

IMPORTANCE OF ENTREPRENURESHIP OF THE RESPONDENT:

\begin{tabular}{|l|l|l|l|}
\hline \multicolumn{1}{|c|}{ S.NO } & \multicolumn{1}{c|}{$\begin{array}{c}\text { Importance of } \\
\text { Entrepreneurship }\end{array}$} & Frequency & \multicolumn{1}{|c|}{ Percentage } \\
\hline 1 & Competency skill & 197 & 39.03 \\
\hline 2 & Creativity & 176 & 35.03 \\
\hline 3 & Empowerment national & 74 rnal & 14.08 \\
\hline 4 & Self efficiency & 49 & 9.08 \\
\hline & Total & 500 & 100.00 \\
\hline
\end{tabular}

From the above table $39.3 \%$ of the respondents were competency skill, $35.3 \%$ of them were creativity, $14.8 \%$ of them were empowerment, $9.8 \%$ them were self efficiency with overall importance : of entrepreneurship. $50.7 \%$ of the respondents were rank 1 as own boss, $35.3 \%$ of the respondents reported they want to be independent, $32.7 \%$ respondents communicated to improve the society and $56.5 \%$ selected they would face barrier on selecting entrepreneurship, $66.7 \%$ feel positive on the opinion on selecting entrepreneurships.

\section{FINDINGS \& SUGGESSTION}

The majorities of respondents was male and were in the age group between 18 to 25 , their monthly income range between 15000 to 25000. Most of the respondents preferred to take self employment and become entrepreneurship and the motivating factor is towards entrepreneurship. The results provide that there is a significant relationship between age of the students and attitude towards entrepreneurship education. The scope level is higher in terms of economic growth and adaption of new technology.
From the above table $52.8 \%$ of the respondents for commerce, $35.4 \%$ for computer science, $6.4 \%$ for management stream, and $5.4 \%$ for others. Majority $52.8 \%$ of the respondents for commerce.

\section{Income of the Respondents}

The monthly income of the respondents are $32 \%$ between Rs.15000-25000, 27\% of a monthly income between above $35000,23 \%$ of they had a monthly income between Rs.25000-35000, $16.6 \%$ of the had a monthly income below 15000 .

\section{SUGGESTION:}

Entrepreneurial culture is common among a student. The 4 Government, entrepreneurial supports programmers should take steps to motivate the students in the manufacturing sector with high innovativeness. The students are ready to face the challenges associated with entrepreneurship, have positive attitude towards entrepreneurship due to the regulations between self-employment and formal employment many of them are not ready to take entrepreneurship as their career choice. The study suggested that the students need to be given updates through entrepreneurial workshops and conferences in various fields to establish the new ventures in the future. The Government has to extend more support in diverse areas to entrepreneurial activities.

1) It was found that only 36 percent of the students were aware of any entrepreneurship development agencies. In order to create an entrepreneurial culture in campus it is necessary to create awareness about entrepreneurship and entrepreneurship development agencies. The institute should have tie-ups with 
entrepreneurship development agencies to create awareness about entrepreneurship and entrepreneurial opportunities

2) Almost all the institutes surveyed (91 percent) had a placement cell in the campus, where only 65 percent institutes had an entrepreneurship development cell. Although the percent is satisfactory, the entrepreneurship development cell should be strengthened and prepare a calendar of activities to be conducted throughout the year.

\section{CONCLUSION:}

Based on the results above, there are a number of conclusions that can be given. First, students have a positive attitude towards entrepreneurship and they understand and appreciate the role the programmer plays in developing entrepreneurship knowledge and skills. Second, as a result of participation in the entrepreneurship education programme, many of the students show willingness to engage in entrepreneurship activities after completing schooling. Third, age and area of specialization have no influence on the attitude of students towards entrepreneurship education while gender has an influence. Fourth, challenges that have a potential of affecting the motivation of students to participate in entrepreneurship activities after completing school include accessing seed money as well as a lack of business opportunities. Finally, it is also concluded that legislation in Botswana is very conducive to the promotion of entrepreneurship activities.

\section{REFERENCE:}

1. Bechard, J.P,. \& J.M. Toulous (1998). Validation of a didactic model for the analysis of training objectives in entrepreneurship. Journal of Business Venturing, 13,317-332.

2. Schaper, M., \& T. Volery (2004). Entrepreneurship and small business: A Pacific Rim perspective. Milton, Queensland, John Wiley and Sons Australia Ltd.

3. Matlay, H., \& P. Westhead (2005). Virtual teams and the rise of e-entrepreneurship in Europe. International Small Business Journal, 12(3), 353365.

4. Venkatachalam, V.B., \& Waqif, A.A. (2005). Outlook on integrating entrepreneurship in management education in India. Decision, 32(2), 57-71.
5. Scarborough, N. M., \& T. W. Zimmerer (2003). Effective small business management: An entrepreneurial approach. Upper Saddle River, NJ, Prentice Hall.

6. Kuratko, D.F. \& Hodgetts, R.M. (2004). Entrepreneurship: Theory, Process. Practice (Mason, OH; South-Western Publishers).

7. Gorman, G., Hanlon, D., \& King, W. (1997). Some research perspectives on entrepreneurship education, enterprise education and education for small business management: a ten-year literature review, International Small Business Journal. 15(3), 56-79.

8. Lena, L., \& Wong, P. K. (2003). Attitude towards entrepreneurship education and new venture creation. Journal of Enterprising Culture, 11(4), 339-357.

9. Karanassios, N., M. Pazarskis, et al. (2006). EU strategies to encourage youth entrepreneurship: Evidence from higher education in Greece. Industry \& Higher Education February, 43-50.

10. Lee, S.M., Chang. D., \& Lim, S. (2005). Impact of entrepreneurship education: a comparative study of the US and Korea. The International Entrepreneurship and Management Journall, 1,2743.

11. Brown, D. R. (1999) J. Neurosci. Res., in the press

12. Teixeira, A. A.C., \& Davey T. (2008), Attitudes of Higher Education students to new venture creation: a preliminary approach to the Portuguese case, Working Papers, Universidad do Porto.

13. Alain, F., Benoit, G., \& ClercNarjisse, L. (2006). Effect and Counter-effect of Entrepreneurship Education and Social Context on Student's Intentions. Estudios de EconomíaAplicada, 24(2), 509-523.

14. Friendrich, C., \& Visser, K. (2005). South Africans Educan and Training. De Dooms, leap Publishing.

15. Green, S. and Pryde, P. (1990). Black entrepreneurship in America. New Brunswick. NJ, Transactions Publishing.

16. Dimitrova, M., Yovevab, I., \& Kamenovac, D. (2012). University students' attitudes and intentions towards entrepreneurial education. IUC Annual Book, 5. 
17. Keat, O. Y., Selvarajah, C., \& Meyer, D. (2006). Inclination towards entrepreneurship among university students : An empirical study of Malaysian university students, 2006.

18. Kgagara, M. R. (2011). An assessment of the attitude towards entrepreneurship among higher education students in Sedibeng district, (November). $1151 \mid \mathrm{P}$ a g e

19. Manuere, F., Danha, K., \& Majoni, T. (2013). Entrepreneurship attitudes and knowledge : a survey of fourth year university students. Interdisciplinary journal of contemporary research in business, 4(9), 511-521.

20. Obembe, E., Otesile, O., \& Ukpong, I. (2014). Understanding the students ' perspectives towards entrepreneurship. Procedia - Social and Behavioral Sciences, 145, 5-11. http://doi.org/10.1016/j.sbspro.2014.06.005

21. hapero, A (1975). The displaced, uncomfortable entrepreneur. Impact of College Entrepreneurial Education on Entrepreneurial Attitudes. Psychology Today, 9, 83-88. 